\title{
The influence of proanthocyanidin-rich bean hulls and level of dietary protein on energy metabolizability and nutrient digestibility by adult cockerels
}

\author{
BY M. A. LONGSTAFF, ${ }^{1}$ D. FEUERSTEIN, ${ }^{2}$ J. M. MCNAB ${ }^{3}$ \\ AND C. MCCORQUODALE ${ }^{3}$ \\ ${ }^{1}$ Department of Biological Sciences, Heriot-Watt University, Riccarton, Edinburgh EHI4 $4 A S$ \\ ${ }^{2}$ Institute KTZ-470, Garbenstrasse, 17, 7000 Stuttgart 70, West Germany \\ ${ }^{3}$ Institute of Animal Physiology and Genetics Research, Roslin, Midlothian EH25 9PS
}

(Received 2 January 1991-Accepted 2 October 1992)

\begin{abstract}
Cotyledons and hulls were prepared from twelve varieties of field beans (Vicia faba L.). Adult cockerels were tube-fed either beans, cotyledons or hull diets containing high or low levels of protein. Metabolizable energy coefficients and starch digestibility coefficients were determined for beans, cotyledons and hull diets. Lipid digestibility coefficients from hull diets were also determined. When cotyledons were fed there were no significant differences in the way in which adult cockerels metabolized energy or digested starch from the proanthocyanidin-free and proanthocyanidin-rich varieties (0.780, $0.908,0.775$ and 0.918 respectively). When beans were fed, however, both energy metabolizability and starch digestibility decreased due to the presence of hulls, with proanthocyanidin-rich hulls decreasing values the most to 0.660 and 0.819 respectively, and proanthocyanidin-free hulls decreasing values to a lesser extent to 0.709 and 0.886 respectively. Diets composed of proanthocyanidin-rich hulls depressed metabolizable energy and maize starch digestibility. Their effect on maize starch digestibility, however, was considerably less than that on bean starch. Lipid digestibility was enhanced by proanthocyanidins but only when the protein content of the diet was high. There was a significant correlation $(P<0.05)$ between the vanillin and anthocyanidin formation methods for the estimation of proanthocyanidins $(r 0.779)$. There was also a highly significant regression of bean starch digestibility $v$. proanthocyanidin content of coloured-flowered bean hulls $(P<0.001)$. The regression of maize starch digestibility $v$. hull proanthocyanidins was also significant at $P<0.005$.
\end{abstract}

Proanthocyanidins: Energy metabolism: Starch digestion: Fat digestion: Cockerel

Legumes such as field beans (Vicia faba L.) and peas (Pisum sativum) are important feedingstuffs for both humans and animals. Several studies have investigated the digestibility of their starch component (Guillaume, 1978; Fleming \& Vose, 1979; Longstaff $\& \mathrm{McNab}, 1987$; Yusté et al. 1991). If fully digested the starch would make a substantial contribution to the metabolizable energy value of legumes. However, the fact that metabolizable energy values have been reported to increase after heat treatment (Conan \& Carre, 1989) and after pelleting (Carre et al. 1987) suggests that in the raw state their starches may not be fully digested.

There is less information on the effect of the presence of the hulls on starch digestibility. Stanogias \& Pearce (1985) reported a decreased digestion of all dietary components with increasing intakes of pea hulls by pigs and suggested that these hulls may have contained substances inhibitory to digestive enzymes. Nitsan (1971) showed that by shelling Vicia faba beans their nutritive value for rats was improved. Longstaff \& McNab (1991a) 
demonstrated a reduction in starch, protein and lipid digestibility when proanthocyanidinrich bean hulls were ingested by young chicks due to the inhibition of $\alpha$-amylase ( $E C$ 3.2.1.1), trypsin (EC 3.4.21.4) and lipase (EC 3.1.1.3) in the digestive tract. Griffiths \& Moseley (1980) were the first to show that the activity of $\alpha$-amylase and trypsin in rat digesta could be inhibited and lipase stimulated by feeding rats diets containing $100 \mathrm{~g}$ proanthocyanidin-rich bean hulls $/ \mathrm{kg}$. Their enzyme work, therefore, anticipated subsequent findings that starch and protein digestion may be impaired and may explain the finding by Marquardt et al. (1977) that lipid digestibility was increased in chicks fed on extracts of proanthocyanidins.

In the present study, by feeding beans containing differing levels of proanthocyanidins in their hulls, the effect of proanthocyanidins on energy, starch and lipid digestion was investigated. The question of particular interest was whether proanthocyanidins would have a greater inhibitory effect on a poorly digested starch (bean) than on a well digested starch (maize). Proanthocyanidins are known to interact with proteins (Oh et al. 1980) and, therefore, the possibility of whether a high level of dietary protein would ameliorate their inhibitory effect on starch and lipid digestion was investigated.

\section{EXPERIMENTAL \\ Feedingstuffs}

Twelve varieties of beans (Vicia faba L.) were kindly supplied by Dr Bond of Plant Breeding Institute, Cambridge. They were harvested in 1989 and fed to cockerels 4-5 months after harvest. The beans consisted of seven coloured-flowered varieties (proanthocyanidin-rich) i.e. Punch, Victor, Boxer, LPLS, Bourdon, Corton and Alfred, and five white-flowered varieties (proanthocyanidin-free) i.e. Toret, IB38, 2103, Blandine and Albatross.

In order to provide both cotyledons and hulls for feeding, whole beans were dehulled using a modified pearl barley dehuller and hulls and cotyledons were separated by blowing hulls free using an air blower. Hulls and remaining cotyledons were examined thoroughly and any cross contamination was removed manually. Beans, cotyledons and hulls were ground separately to pass through a $1 \mathrm{~mm}$ sieve. The amount of hull normally present in beans has been found to range from 120 to $140 \mathrm{~g}$ hull $/ \mathrm{kg}$ bean (M. Longstaff, unpublished results).

In three separate experiments whole beans from twelve varieties, cotyledons from twelve varieties or hulls diets prepared from six varieties were fed to adult cockerels. Beans and cotyledons were fed as the only dietary ingredients. Hulls were fed as constituents of simplified diets composed of casein, maize starch and maize oil. There were two types of hull diets: high protein-low starch and low protein-high starch into which hulls were substituted at a level of $300 \mathrm{~g} / \mathrm{kg}$. Thus, the composition of $50 \mathrm{~g}$ high protein-low starch diets was (g) casein 24.5, maize starch 7, maize oil 3.5 and hulls 15 , while that of $50 \mathrm{~g}$ low protein-high starch diets was (g) casein 7, maize starch 24.5 , maize oil 3.5 and hulls 15 . Hulls from six varieties (three proanthocyanidin-rich and three proanthocyanidin-free) were chosen, making twelve different diets in total.

The concentration of gross energy and dietary nutrients in the beans, cotyledons and hull diets is shown in Table 1.

There was very little difference between the white- and coloured-flowered varieties in the concentration of these constituents. It was, therefore, not the flower colour that influenced the level of these constituents ingested but rather whether birds ingested beans, cotyledons or high- or low-protein hull diets and because three separate experiments were conducted this difference in nutrient input was not considered to be an issue. 
Table 1. Energy and nutrient composition of beans, cotyledons and high-and low-protein hull diets

\begin{tabular}{|c|c|c|c|c|c|c|c|c|c|c|c|c|}
\hline \multirow{3}{*}{ Expt... } & \multirow{2}{*}{\multicolumn{3}{|c|}{$\begin{array}{c}1 \\
\text { Beans }\end{array}$}} & \multirow{2}{*}{\multicolumn{3}{|c|}{$\stackrel{2}{\text { Cotyledons }}$}} & \multicolumn{6}{|c|}{3} \\
\hline & & & & & & & \multicolumn{3}{|c|}{ High-protein hull diet } & \multicolumn{3}{|c|}{ Low-protein hull diet } \\
\hline & $\begin{array}{l}\text { Energy } \\
(\mathrm{kJ} / \mathrm{g})\end{array}$ & $\begin{array}{l}\text { Starch } \\
(\mathrm{g} / \mathrm{kg})\end{array}$ & $\begin{array}{l}\text { Protein } \\
(\mathrm{g} / \mathrm{kg})\end{array}$ & $\begin{array}{l}\text { Energy } \\
(\mathrm{kJ} / \mathrm{g})\end{array}$ & $\begin{array}{l}\text { Starch } \\
(\mathrm{g} / \mathrm{kg})\end{array}$ & $\begin{array}{l}\text { Protein } \\
(\mathrm{g} / \mathrm{kg})\end{array}$ & $\begin{array}{r}\text { Energy } \\
(\mathrm{kJ} / \mathrm{g})\end{array}$ & $\begin{array}{l}\text { Lipid } \\
(\mathrm{g} / \mathrm{kg})\end{array}$ & $\begin{array}{l}\text { Starch } \\
(\mathrm{g} / \mathrm{kg})\end{array}$ & $\begin{array}{l}\text { Energy } \\
(\mathrm{kJ} / \mathrm{g})\end{array}$ & $\begin{array}{l}\text { Lipid } \\
(\mathrm{g} / \mathrm{kg})\end{array}$ & $\begin{array}{l}\text { Starch } \\
(\mathrm{g} / \mathrm{kg})\end{array}$ \\
\hline \multicolumn{13}{|l|}{ White } \\
\hline Toret & 16.66 & 345 & 262 & 16.68 & 371 & 286 & $20 \cdot 6$ & $50 \cdot 0$ & 126 & $18 \cdot 1$ & $61 \cdot 8$ & 411 \\
\hline IB38 & $16 \cdot 34$ & 403 & 231 & $16 \cdot 37$ & 414 & 251 & $20 \cdot 6$ & NA & 119 & $18 \cdot 2$ & - & 415 \\
\hline 2103 & $16 \cdot 18$ & 398 & 231 & 16.42 & 420 & 245 & $20 \cdot 8$ & 54.4 & 119 & $18 \cdot 1$ & 54.0 & 406 \\
\hline Blandine & $15 \cdot 94$ & 346 & 232 & $16 \cdot 36$ & 405 & 260 & $20 \cdot 6$ & - & 125 & $18 \cdot 0$ & - & 423 \\
\hline Albatross & $16 \cdot 49$ & 368 & 252 & $16 \cdot 58$ & 406 & 270 & $20 \cdot 7$ & $56 \cdot 3$ & 120 & $18 \cdot 2$ & $51 \cdot 8$ & 409 \\
\hline Mean & $16 \cdot 32$ & 372 & 242 & $16 \cdot 48$ & 403 & 262 & $20 \cdot 7$ & $53 \cdot 6$ & 122 & $18 \cdot 1$ & 55.9 & 413 \\
\hline \multicolumn{13}{|l|}{ Coloured } \\
\hline Punch & $16 \cdot 38$ & 385 & 229 & 16.64 & 418 & 256 & $20 \cdot 9$ & $60 \cdot 9$ & 120 & $18 \cdot 2$ & $55 \cdot 9$ & 420 \\
\hline Victor & $16 \cdot 38$ & 394 & 213 & $16 \cdot 34$ & 441 & 234 & 20.7 & 649 & 126 & $18 \cdot 3$ & $71 \cdot 6$ & 410 \\
\hline LPLS & 16.69 & 315 & 290 & $16 \cdot 89$ & 356 & 324 & $20 \cdot 7$ & NA & 122 & $18 \cdot 2$ & $\mathrm{NA}$ & 438 \\
\hline Boxer & $16 \cdot 21$ & 387 & 229 & $16 \cdot 37$ & 429 & 244 & 20.8 & NA & 120 & $18 \cdot 2$ & NA & 412 \\
\hline Bourdon & $16 \cdot 31$ & 382 & 222 & $16 \cdot 32$ & 408 & 244 & $20 \cdot 8$ & NA & 119 & $18 \cdot 3$ & NA & 408 \\
\hline Corton & 16.41 & 384 & 231 & 16.57 & 437 & 259 & $20 \cdot 6$ & NA & 122 & $18 \cdot 3$ & $\mathrm{NA}$ & 416 \\
\hline Alfred & $16 \cdot 32$ & 375 & 227 & $16 \cdot 37$ & 411 & 251 & 209 & $64 \cdot 4$ & 120 & $18 \cdot 2$ & 67.4 & 407 \\
\hline Mean & $16 \cdot 39$ & 374 & 234 & $16 \cdot 50$ & 414 & 259 & $20 \cdot 8$ & 63.4 & 121 & $18 \cdot 2$ & $65 \cdot 0$ & 416 \\
\hline
\end{tabular}

NA, not analysed.

\section{Bioassay}

Expt 1. Beans. Seventy-two individually-caged adult Isa Brown cockerels of weight 2.5$3 \mathrm{~kg}$ and age 24 weeks were used. They had previously been fed ad lib on a standard diet composed mainly of maize and soya-bean meal, complete with minerals and vitamins. In order to empty the digestive tract they were deprived of food except for the administration of $50 \mathrm{~g}$ granulated glucose fed after $24 \mathrm{~h}$ directly into the crop. After $48 \mathrm{~h}$ they were tubefed $50 \mathrm{~g}$ beans ( $1 \mathrm{~mm}$ sieved) directly into the crop. Six extra cockerels also received $50 \mathrm{~g}$ granulated glucose directly into the crop and these birds were used as controls for the calculation of endogenous energy losses and traces of starch and lipid remaining in the tract after starvation. Trays were placed under each cage and the excreta were collected after $72 \mathrm{~h}$, frozen at $-20^{\circ}$, freeze-dried, weighed and kept for subsequent analysis. Birds were allowed free access to water at all times. All twelve bean varieties were fed randomly to seventy-two birds, six birds per bean variety.

Expt 2. Cotyledons. The same seventy-two cockerels, having been fed ad lib on a standard diet as previously described for 3 weeks, were deprived of food for $48 \mathrm{~h}$, except for the administration of glucose, and tube-fed $50 \mathrm{~g}$ cotyledons $(1 \mathrm{~mm}$ sieved) directly into the crop. Six extra birds were also fed on $50 \mathrm{~g}$ glucose. All twelve cotyledon varieties were fed randomly to seventy-two birds, six birds per cotyledon variety. Excreta were collected after $72 \mathrm{~h}$ as described previously.

Expt 3. Hull diets. After a further 3 weeks of feeding a standard diet ad lib., the same seventy-two adult cockerels were deprived of food for $48 \mathrm{~h}$ except for the administration of glucose and tube-fed $50 \mathrm{~g}$ hull diets $(1 \mathrm{~mm}$ sieved) directly into the crop. Six extra birds were also fed on $50 \mathrm{~g}$ glucose. Diets were fed randomly to seventy-two birds, six birds per diet. Excreta were collected after $72 \mathrm{~h}$ as described previously. 


\section{Measurement of energy}

The gross energies of beans, cotyledons, diets and excreta were determined using a Parr adiabatic bomb calorimeter. The energy found in excreta from control birds was used to determine endogenous energy losses. Because birds excrete both uric acid and faeces together, the energy measured is metabolizable energy and not merely digestible energy which would be obtained if only the faeces were collected. It is usual to express the metabolizable energy of a feedstuff on a $\mathrm{kJ} / \mathrm{g}$ food input basis (McNab \& Blair, 1988). In the present study, because a difference of $2 \mathrm{KJ} / \mathrm{g}$ energy input between the high- and lowprotein diets would influence the energy output and, hence, obscured the ability to detect differences between treatments due to proanthocyanidins, metabolizable energy was expressed relative to gross energy intake, i.e. a metabolizability coefficient.

\section{Measurement of lipid}

Lipid in diets and excreta was measured after its extraction with acidic light petroleum (b.p. $40-60^{\circ}$ ) according to the method of the European Communities (1971) procedure B.

\section{Measurement of starch}

Reducing sugars in cotyledons, beans, diets and excreta were measured quantitatively using the reagent $p$-hydroxybenzoic acid hydrazide (PAHBAH) which reacts to form a yellow chromogen which is measured spectrophotometrically (Lever, 1972; Hudson \& John, 1976; Tawflick \& Mardon, 1985). Starch was converted to the reducing sugar glucose by the enzymic action of amyloglucosidase (EC 2.3.1.3; Sigma Chemical Co.) which will hydrolyse both $\propto 1-6$ and $\alpha 1-4$ links in gelatinized starch. Feedingstuffs $(50 \mathrm{mg})$ and excreta $(100 \mathrm{mg})$ were weighed into polypropylene tubes and $9 \mathrm{ml} 0 \cdot 2 \mathrm{M}$-sodium acetate buffer, $\mathrm{pH} 4.5$, was added. The capped tubes were placed in an oven at $100^{\circ}$ for $4 \mathrm{~h}$ in order to gelatinize the starch. On cooling to below $50^{\circ}, 1 \mathrm{ml}$ sodium acetate buffer, with or without $0 \cdot 1 \mathrm{mg}$ amyloglucosidase, was added and the contents were incubated at $50^{\circ}$ in a shaking water-bath for $16 \mathrm{~h}$. After cooling, $0 \cdot 2 \mathrm{ml}$ supernatant fractions were diluted to $20 \mathrm{ml}$ with distilled water and reducing sugars measured colorimetrically after reaction with PAHBAH.

\section{Extraction of proanthocyanidins}

Hulls $(50 \mathrm{mg})$ were weighed into universal bottles and $7.5 \mathrm{ml}$ aqueous acetone (acetone-water; $3: 1, v / v$ ) was added. Bottles were capped and placed on spiramix rollers for $2 \mathrm{~h}$. After centrifugation at $2400 \mathrm{~g}$ for $10 \mathrm{~min}$ supernatant fractions were decanted into specimen bottles either to be used immediately or kept at $4^{\circ}$ until required. No change was found to occur in proanthocyanidin content with storage over 1 week. Two methods of measurement were carried out on the same extracts.

\section{Measurement of proanthocyanidins}

(A) The vanillin method as described by Butler et al. (1982) was used. In this method the end-groups of proanthocyanidin polymers react with vanillin to form a pink chromogen which is measured colorimetrically at $510 \mathrm{~nm}$. The reaction was carried out at room temperature since no strict control of temperature was found to be necessary. Portions $(0.2 \mathrm{ml})$ of aqueous acetone extracts were diluted to $1.0 \mathrm{ml}$ with glacial acetic acid and $5.0 \mathrm{ml}$ vanillin reagent $(5 \mathrm{ml}$ vanillin/1 glacial acetic acid containing concentrated $\mathrm{HCl}(40 \mathrm{ml} / \mathrm{l})$ ) was added and solutions were mixed. Two standards were used, catechin (Sigma Chemical Co.) and a laboratory purified proanthocyanidin prepared from bean hulls by aqueous acetone extraction followed by passage through Sephadex LH20. Care was taken to ensure 
that the standards contained the same amount of aqueous acetone as the samples since the presence of water was found to depress colour formation (M. Longstaff, unpublished results). Results were expressed as catechin equivalents and also as proanthocyanidin concentration.

(B) The method of Porter et al. (1986) for the measurement of anthocyanidin formation was used. When proanthocyanidins are heated in acidified butanol they undergo oxidative degradation with the formation of coloured anthocyanidins. Although complete conversion to anthocyanidins does not occur it was found that when using a purified proanthocyanidin standard from bean hulls colour formation was proportional to concentration over a suitable working range. Portions of aqueous acetone extracts $(0.2 \mathrm{ml})$ were diluted to $1.0 \mathrm{ml}$ with aqueous acetone and $6 \mathrm{ml}$ acidified butanol (butan-1-ol-concentrated $\mathrm{HCl}$; $95: 5, \mathrm{v} / \mathrm{v})$ and $2 \mathrm{ml}$ ammonium ferric sulphate $(20 \mathrm{~g} / 1)$ were added. Tubes were capped and heated for $1 \mathrm{~h}$ at $100^{\circ}$. On cooling, the magenta colour that formed was determined immediately at $550 \mathrm{~nm}$. In this method purified proanthocyanidin was used as a standard since catechin does not form a coloured product with acidified butanol.

\section{Calculation of metabolizabilities}

Metabolizability coefficients for energy and digestibility coefficient for starch and lipid were calculated according to the equation:

$$
\text { coefficient }=\frac{\text { ingested }-(\operatorname{excreted}-\operatorname{excreted}(\mathrm{Gl}))}{\text { ingested }},
$$

where Gl are glucose control birds and ingested is test diet excluding glucose.

\section{Statistical methods}

Digestibility or metabolizability coefficients for each bird were transformed to the logistic scale (Atkinson, 1985) where variances between birds within the variety-bean part or variety-protein level treatment groups were approximately constant. Analysis of variance in this scale between and within treatment groups were then performed to estimate the constant variance for each variate.

Tables 2-6 contain the means of untransformed digestibility or metabolizability coefficients for each treatment group and means of these means for the flower type-bean part or flower type-protein level combinations. Also presented are the corresponding means of means of the transformed digestibility coefficients with their standard errors, calculated from the residual mean square between birds within treatments provided by the analysis of variance.

Statistical significance probabilities quoted in the text and tables were calculated by comparing Student's $t$ statistic with the percentage points of the $t$ distribution or the variance ratio with the percentage points of the $\mathrm{F}$ distribution. In all cases the residual mean square between birds within treatments provided by the analysis of variance in the logistic scale was used as the error variance.

The effect of flower type in Tables 1-5 refers to the average difference in the logistic scale between the particular white- and coloured-flowered varieties actually used. Varieties were regarded as a fixed rather than a random effect (Snedecor \& Cochran, 1967).

\section{RESULTS}

Metabolizability coefficients of energy of cotyledons and beans are shown in Table 2 . Cotyledons of both white- and coloured-flowered varieties $(0.780,0.776$ respectively) were 
Table 2. The influence of bean variety and bean part* on the metabolizability of energy by cockerels

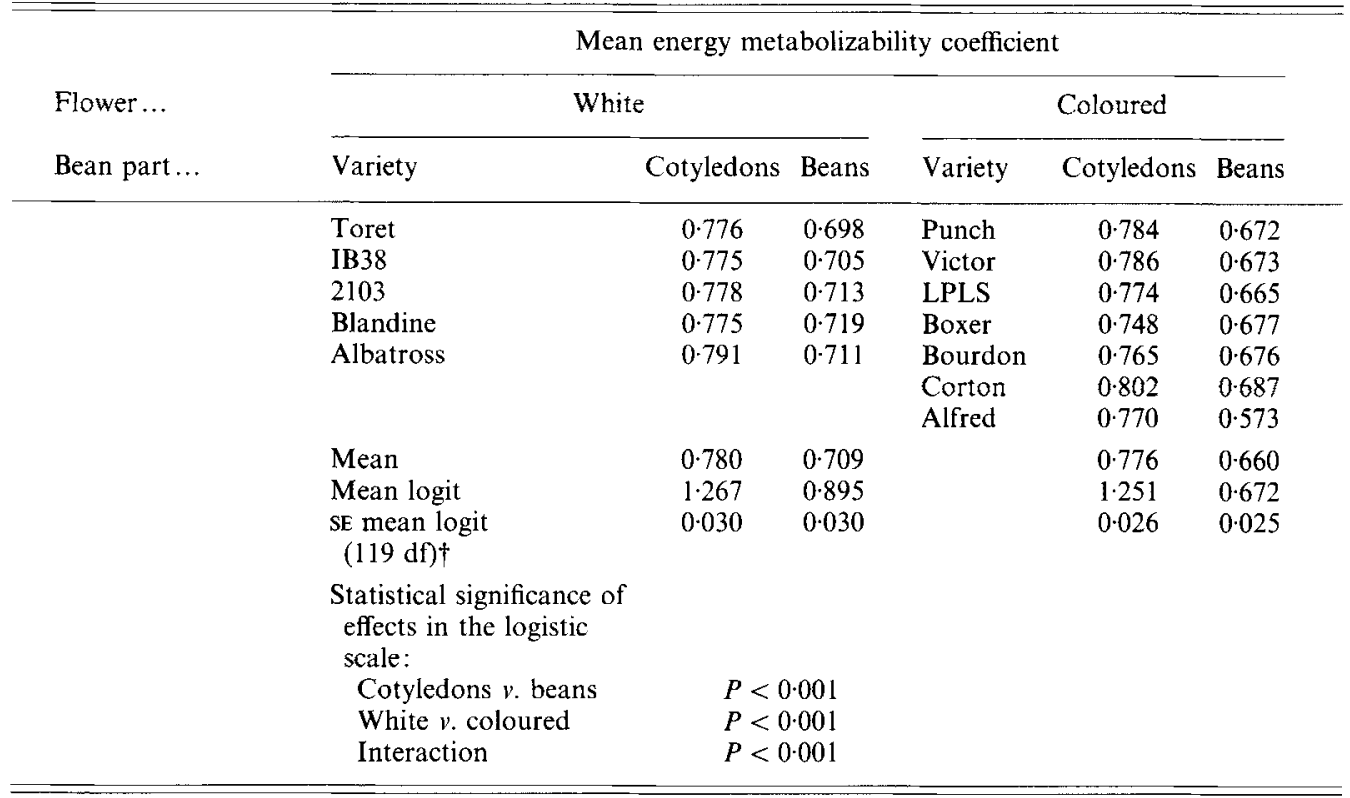

* For details of composition, see Table 1.

$\dagger$ Six birds per variety-bean part group with one observation missing in the group fed on Corton cotyledons.

significantly higher in energy compared with beans $(0.709,0.660)$. These differences were highly significant $(P<0.001)$. Cotyledons of both flower varieties provided equal amounts of energy ( 0.780 and 0.776 for white and coloured respectively), whereas beans from the white-flowered varieties provided more energy $(0 \cdot 709)$ than those from the coloured varieties (0.660). This difference between flower types $(P<0.001)$, which was only observable when beans were fed, resulted in a highly significant interaction $(P<0.001)$. Differences between individual beans within the coloured-flower varieties were also significant at $P<0.001$, with Alfred giving the lowest energy metabolizability coefficients.

Starch digestibilities of cotyledons and beans are shown in Table 3. Starch digestibilities in cotyledons from both white- and coloured-flowered varieties were similar $(0.908$ and 0.918 respectively). There was, however, a highly significant difference $(P<0.001)$ in starch digestibility between cotyledons $(0.908,0.918)$ and beans $(0.886,0.819)$ for white- and coloured-flowered varieties respectively. This difference was small, however, for the whiteflowered varieties and large for the coloured-flowered varieties, resulting in a highly significant interaction $(P<0.001)$. Differences within the coloured-flowered varieties were also significant $(P<0.001)$, with Alfred causing the worst starch digestion.

The influence of hull variety and protein level on the metabolizable energy coefficient is shown in Table 4. There was an overall significant increase in energy metabolizability $(P<0.001)$ when hulls from the white-flowered varieties were present. Metabolizabilities, however, were similar in diets containing hulls from white- and coloured-flowered varieties when the protein content was high $(0.680,0.676)$. When the protein content was low, birds derived about $8 \%$ more energy from the white-flowered hull diets than the colouredflowered hull diets $(0.728$ and 0.686 respectively), the interaction being highly significant 
Table 3. The influence of bean variety and bean part* on the digestibility of starch by cockerels

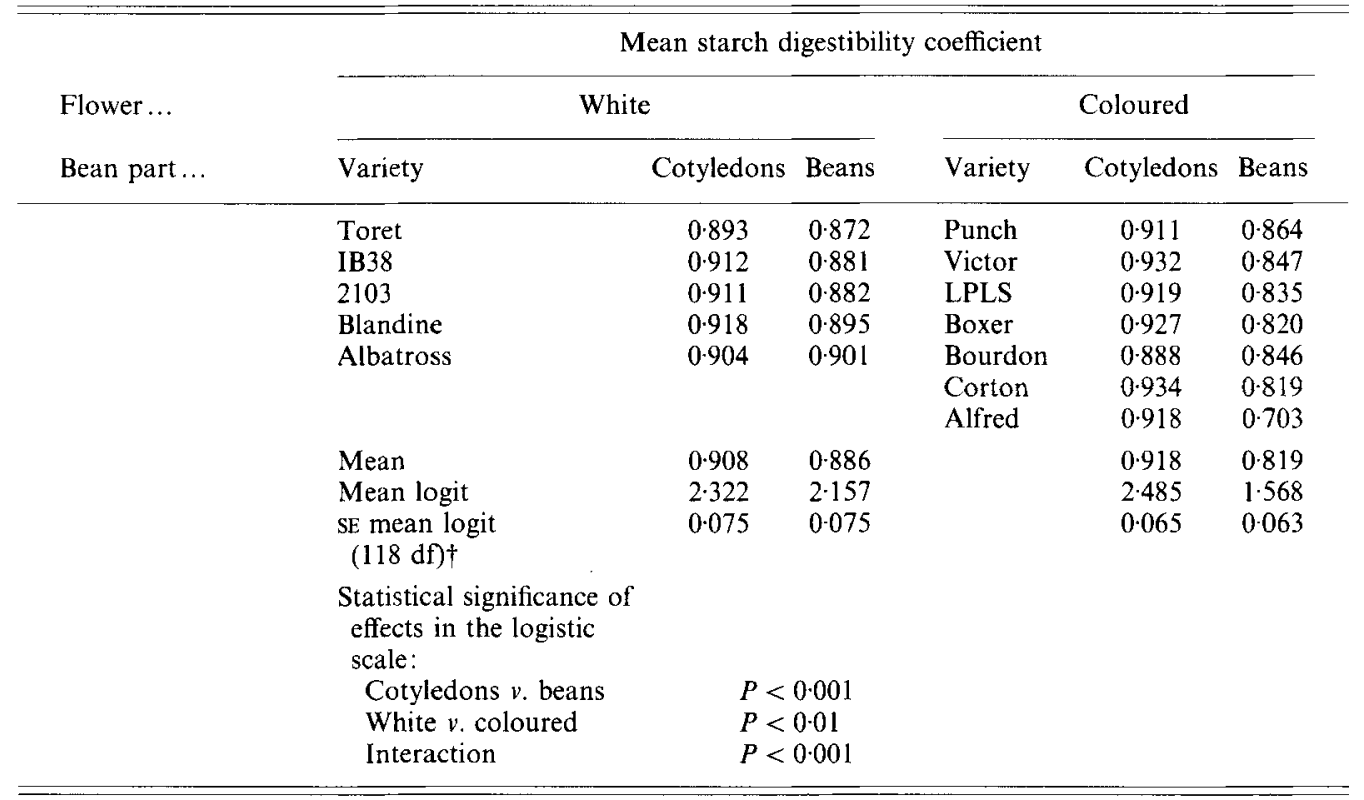

* For details of composition, see Table 1.

$\dagger$ Six birds per variety-bean part group with one observation missing in the group fed on Corton cotyledons and one observation missing in the group fed on Boxer cotyledons.

$(P<0.001)$. Hull varieties within a flower type and protein level showed no statistical significance at the $5 \%$ level.

The influence of hull variety and protein level on digestibility of starch in the maize diet is shown in Table 5 . Hulls from the coloured-flowered varieties significantly reduced starch digestibility $(P<0.05)$. The magnitude of this reduction, however, was small, a decrease from 0.975 to 0.973 for high-protein diets and from 0.992 to 0.989 for low-protein diets when white- and coloured-flowered hulls were fed respectively. A high dietary protein level significantly lowered starch digestibility $(P<0.001)$, but there was no interaction of protein with hull flower colour. Differences within flower types and protein levels were not significantly different at the $5 \%$ level.

The influence of hull variety and protein level on digestibility of lipid is shown in Table 6. Hulls from the coloured-flowered varieties significantly increased the digestibility of lipid, the overall effect being significant at $P<0 \cdot 01$. There was no significant effect of protein level on lipid digestibility. However, when the protein content of the diet was high, birds fed on the coloured-flowered hulls digested significantly more lipid (0.922) than birds fed on the white-flowered hulls $(0.874)$, whereas when the protein content of the diet was low, birds digested lipid equally well from diets containing coloured- $(0 \cdot 899)$ and white$(0.897)$ flowered hulls. Differences between varieties within flower types and protein levels were not significantly different at the $5 \%$ level.

The proanthocyanidin content of the hulls from the twelve varieties are shown in Table 7. No proanthocyanidins were detected in the hulls from the white-flowered varieties. When catechin was used as a standard in the vanillin method, values expressed as $\mathrm{g}$ catechin 
Table 4. The influence of hull variety and protein level on the metabolizability of energy by cockerels*

\begin{tabular}{|c|c|c|c|c|c|c|}
\hline \multirow{3}{*}{$\begin{array}{l}\text { Flower... } \\
\text { Protein ... }\end{array}$} & \multicolumn{6}{|c|}{ Mean energy metabolizability coefficient } \\
\hline & \multicolumn{3}{|c|}{ White } & \multicolumn{3}{|c|}{ Coloured } \\
\hline & Variety & High & Low & Variety & High & Low \\
\hline & Toret & 0.666 & 0.735 & Punch & 0.690 & 0.687 \\
\hline & IB38 & 0.679 & 0.723 & Victor & 0.676 & 0.677 \\
\hline & 2103 & 0.692 & 0.737 & LPLS & 0.676 & 0.682 \\
\hline & Blandine & 0.683 & 0.730 & Boxer & 0.678 & 0.699 \\
\hline & Albatross & 0.681 & $0 \cdot 716$ & Bourdon & 0.683 & 0.690 \\
\hline & & & & Corton & 0.645 & 0.695 \\
\hline & & & & Alfred & 0.678 & 0.673 \\
\hline & Mean & 0.680 & 0.728 & & $0 \cdot 675$ & 0.686 \\
\hline & Mean logit & 0.757 & 0.987 & & 0.733 & 0.783 \\
\hline & $\begin{array}{l}\text { SE mean } \\
(47 \mathrm{df}) \dagger\end{array}$ & 0.023 & $0 \cdot 023$ & & $0 \cdot 020$ & 0.019 \\
\hline & \multicolumn{3}{|c|}{$\begin{array}{l}\text { Statistical significance of } \\
\text { effects in the logistic } \\
\text { scale: }\end{array}$} & & & \\
\hline & \multicolumn{2}{|c|}{ White $v$. coloured } & & & & \\
\hline & High $v$. low protein & & & & & \\
\hline & Interactio & \multicolumn{2}{|c|}{$P<0.001$} & & & \\
\hline
\end{tabular}

* For details of diets and procedures, see Table 1 and pp. 356-359.

$\dagger$ Three birds per variety-bean part group with one observation missing in the group fed on the high-protein diet with Boxer hulls.

equivalents $/ \mathrm{kg}$ were very much lower than when a purified proanthocyanidin from bean hulls was used. The vanillin method (A), using purified proanthocyanidin as standard, and the anthocyanidin formation method (B), using the same standard, gave very similar trends between the varieties, the correlation coefficient of 0.779 being significant at $P<0.005$. However, method A estimated a slightly higher amount of proanthocyanidins than method $\mathrm{B}$, the mean difference being 1.65 (SD 0.399$) \mathrm{g} / \mathrm{kg}$. A highly significant difference in proanthocyanidin concentration $(P<0.001)$ was found between varieties using method $\mathrm{B}$, variance ratio 8.61 with 6 and $21 \mathrm{df}$. Athough the range in values was fairly small, there were nevertheless significant linear regression coefficients of bean (Table 3 ) and maize starch (Table 5) digestibilities in the logistic scale on proanthocyanidin content of hulls ( $P<0.001$ and $P<0.005$ respectively). The variance ratios were 18.55 with 1 and $118 \mathrm{df}$ and 6.40 with 1 and $47 \mathrm{df}$ for bean and maize starch regressions respectively.

\section{DISCUSSION}

Although proanthocyanidins per se were not fed to cockerels in the present study, these substances account for the main difference between coloured- and white-flowered bean hulls (Longstaff \& McNab, 1991 a), their presence ranging from 167.9 to $209.6 \mathrm{~g} / \mathrm{kg}$ hull (Table 7) as estimated by the vanillin method (Butler et al. 1982). Yuste et al. (1992) confirmed that proanthocyanidins extracted in aqueous acetone from the hulls of field beans lowered nutrient digestion and digestive enzyme activities. Fibre, which constitutes about $902 \mathrm{~g} / \mathrm{kg}$ hull of white-flowered bean hulls (Longstaff \& McNab, 1991 a), can also lower nutrient digestibility by acting as enzyme inhibitors (Schneeman, 1978; Longstaff \& $\mathrm{McNab}, 1991 \mathrm{a}$ ). Because the white-flowered varieties of beans and hulls were also fed to 
Table 5. The influence of hull variety and protein level on the digestibility of maize starch by cockerels*

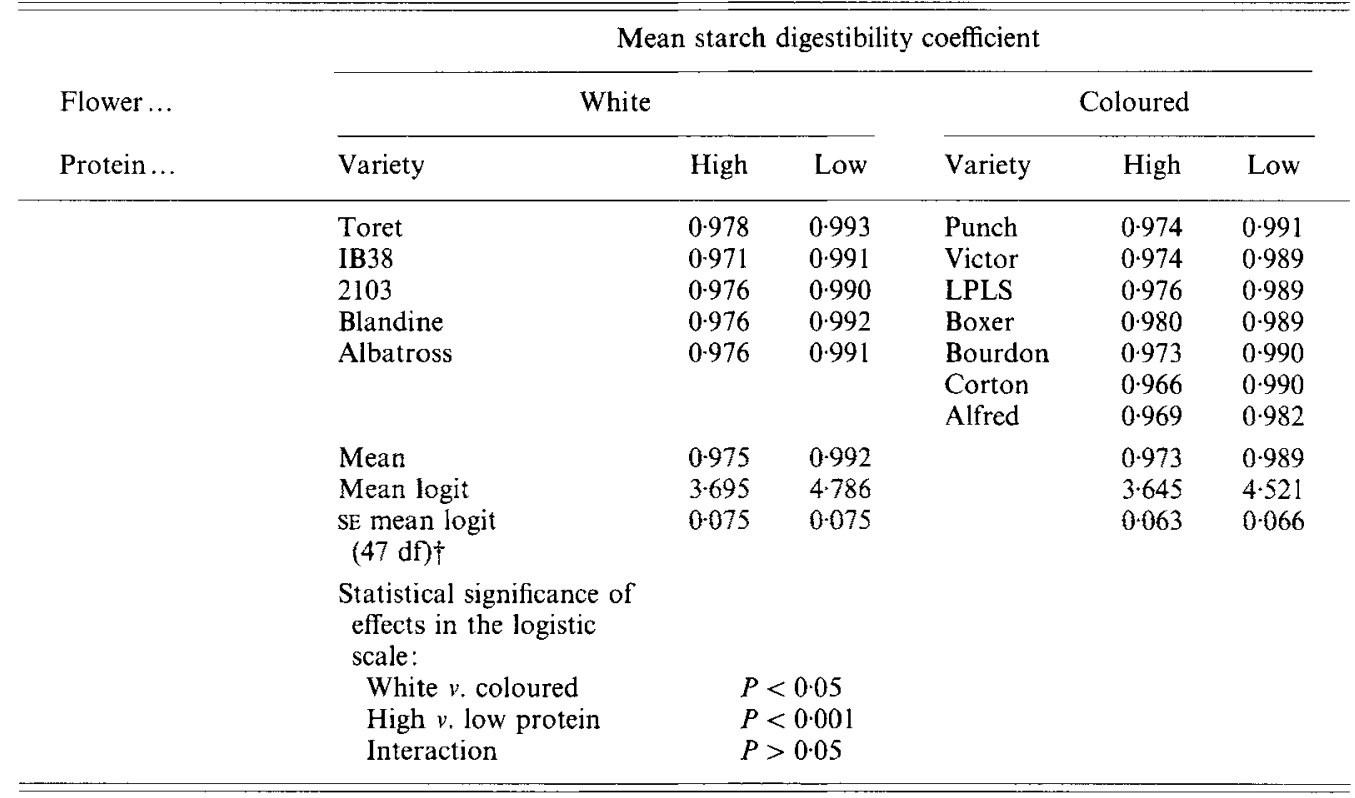

* For details of diets and procedures, see Table 1 and pp. 356-359.

$\uparrow$ Three birds per variety-protein level group with one observation missing in the group fed on the low-protein diet with Boxer hulls.

Table 6. The influence of hull variety and protein level on the digestibility of lipid by cockerels*

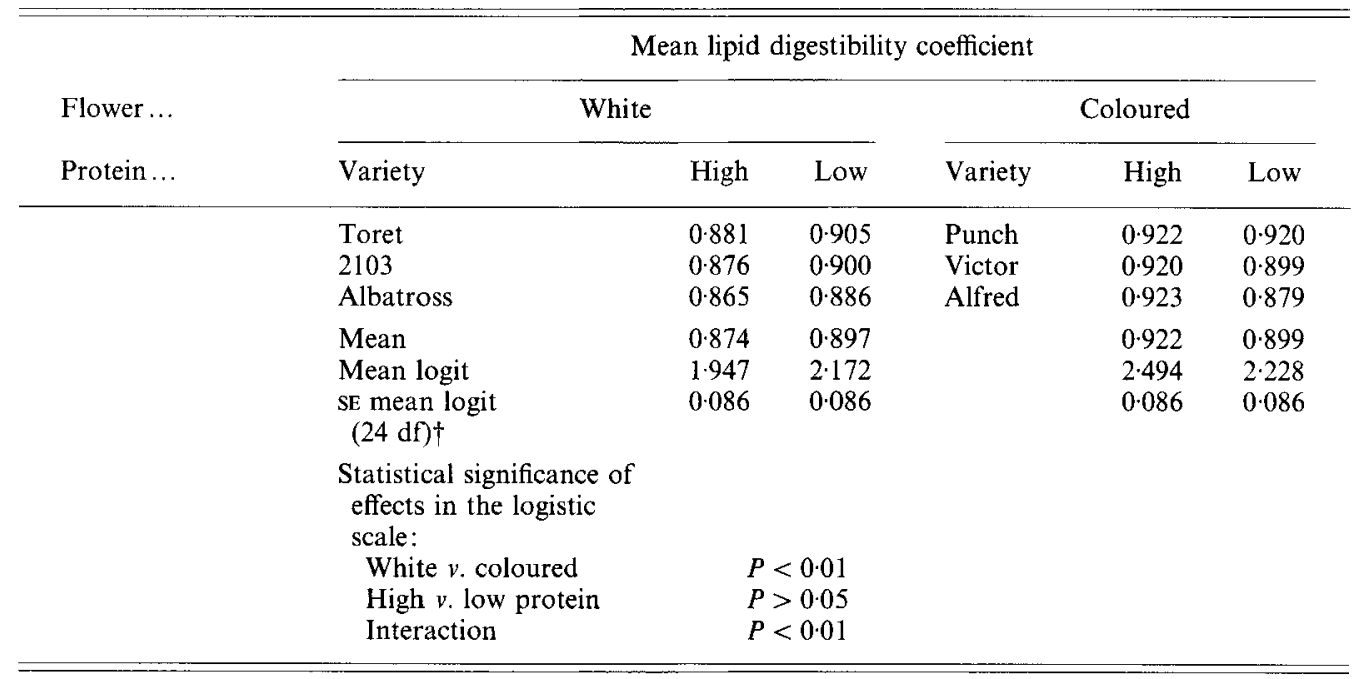

* For details of diets and procedures, see Table 1 and pp. 356-359.

$\dagger$ Three birds per variety-protein level group. 
Table 7. Proanthocyanidin content $(\mathrm{g} / \mathrm{kg})$ of hulls from twelve varieties of field beans (Vicia faba $L$.)

(Mean values with their standard deviations)

\begin{tabular}{|c|c|c|c|c|c|c|}
\hline \multirow[b]{3}{*}{ Variety } & \multicolumn{4}{|c|}{ Method A } & \multirow{2}{*}{\multicolumn{2}{|c|}{$\begin{array}{c}\text { Method B } \\
\text { Proanthocyanidin } \dagger\end{array}$}} \\
\hline & \multicolumn{2}{|c|}{ Catechin equivalents* } & \multicolumn{2}{|c|}{ Proanthocyanidin $\dagger$} & & \\
\hline & Mean & SD & Mean & SD & Mean & SD \\
\hline \multicolumn{7}{|l|}{ Coloured } \\
\hline Punch & $34 \cdot 1$ & $2 \cdot 7$ & $167 \cdot 9$ & $16 \cdot 4$ & $165 \cdot 8$ & $5 \cdot 6$ \\
\hline Victor & $37 \cdot 6$ & $2 \cdot 1$ & $185 \cdot 1$ & $15 \cdot 9$ & $161 \cdot 4$ & $10 \cdot 2$ \\
\hline LPLS & $38 \cdot 4$ & $2 \cdot 7$ & $189 \cdot 0$ & $17 \cdot 4$ & $168 \cdot 3$ & $3 \cdot 0$ \\
\hline Boxer & $37 \cdot 1$ & $2 \cdot 3$ & $182 \cdot 8$ & $13 \cdot 9$ & $174 \cdot 6$ & $7 \cdot 4$ \\
\hline Bourdon & 39.9 & $2 \cdot 2$ & $197 \cdot 3$ & $16 \cdot 4$ & $176 \cdot 8$ & $8 \cdot 5$ \\
\hline Corton & $40 \cdot 3$ & $2 \cdot 2$ & $198 \cdot 5$ & $15 \cdot 9$ & $174 \cdot 2$ & $6 \cdot 6$ \\
\hline Alfred & $43 \cdot 2$ & $3 \cdot 6$ & $209 \cdot 6$ & $23 \cdot 2$ & $193 \cdot 3$ & $5 \cdot 3$ \\
\hline \multicolumn{7}{|l|}{ White } \\
\hline Toret & \multirow[t]{5}{*}{0} & & \multirow[t]{5}{*}{0} & & \multirow{5}{*}{\multicolumn{2}{|c|}{0}} \\
\hline IB38 & & & & & & \\
\hline 2103 & & & & & & \\
\hline Blandine & & & & & & \\
\hline Albatross & & & & & & \\
\hline
\end{tabular}

Method A, vanillin reaction (Butler, et al. 1982); method B, anthocyanidin formation (Porter et al. 1986).

* Catechin used as standard.

$\uparrow$ Purified bean hull proanthocyanidin used as standard.

cockerels, these acted as controls to compensate for any effect of fibre augmenting that of proanthocyanidins or digestion.

When beans were ingested by adult cockerels the starch from coloured-flowered varieties was less well digested than that from white-flowered varieties. This suggests that the proanthocyanidins present in the hulls of the coloured-flowered varieties might have been responsible for this effect since there were no differences in starch digestion between whiteand coloured-flowered varieties when cotyledons alone were fed. Furthermore, the large difference in starch digestibility (from 0.864 to 0.703 ) within the coloured-flowered varieties could possibly be explained by differences in proanthocyanidin content of their hulls. Consequently, it was found that there was a highly significant $(P<0.001)$ linear regression of the means (in the logistic scale) of bean starch digestibility on the proanthocyanidin content of the hulls as estimated by the anthocyanidin formation method. Lindgren (1975) showed a highly significant negative correlation between the proanthocyanidin content of field beans and peas and the digestibility of their crude protein $(r-0 \cdot 82)$.

When birds were fed on the hull diets containing maize starch the overall effect of hulls from the coloured-flowered compared with white-flowered beans on starch digestibility, although significant at $P<0.05$ was exceedingly small. There was no significant difference within the coloured-flowered varieties on their effect on starch digestibility and it was only when the regression of maize starch digestibility $v$. proanthocyanidin hull content was done that a significant effect was demonstrated at $P<0.005$. Such exceedingly good digestibility of maize starch even in the presence of proanthocyanidins precluded the ability to observe any interaction of dietary protein with proanthocyanidins on starch digestion.

Results from the present study suggest that proanthocyanidin-rich hulls exhibit a large or a small effect on starch digestibility depending on how well the starch is digested in the 
first place. The poorer digestibility of legume starch compared with graminaceous starch has already been reported (Longstaff \& $\mathrm{McNab}, 1986,1987$ ). Yusté et al. (1991), by feeding diets containing semi-purified starches and a digestive marker (titanium dioxide), showed that starches from peas and beans were less well digested by young chicks than those from wheat and maize, and demonstrated that their digestion took much longer. From analysis of digesta removed from the proximal and distal ileum of chicks killed by injection of sodium pentobarbitone, a further $4 \%$ of pea starch and $17 \%$ of bean starch was found to be digested after the digesta passed from proximal to distal ileum, while wheat and maize starches were fully digested at the proximal ileum. It may be precisely this slowness and incompleteness of digestion higher up the digestive tract that is the necessary prerequisite for proanthocyanidins to exhibit a larger anti-nutritional effect. Thus, if wheat or maize starch digestibility was slowed down then proanthocyanidins might well inhibit the digestion of these starches to a greater extent. An explanation of this kind would account for the large effect of proanthocyanidin-rich hulls on decreasing maize starch digestibility in a previous experiment (Longstaff \& $\mathrm{McNab}, 1991 \mathrm{a}$ ) when hulls $(400 \mathrm{~g} / \mathrm{kg}$ ) were fed to young chicks twice daily for $4 \mathrm{~d}$. On that occasion, perhaps due to the greater concentration of hulls, movement of food out of the crop was observed to be slow suggesting that the rate of passage of digesta further down the tract was also slow, thus making starch digestibility more susceptible to the effect of proanthocyanidins.

In the present study proanthocyanidin-rich hulls appeared to aid the digestion of lipid especially when the protein content of the diet was high. Unfortunately, the experimental design did not permit the measurement of lipase activity. Marquardt et al. (1977) also reported increased lipid digestion by chicks fed on proanthocyanidin-rich hulls, and Horigome et al. (1988) and Griffith \& Moseley (1982) have reported an increase in lipase activity in rats after the ingestion of proanthocyanidins. Longstaff \& McNab (1991b) showed that an increased lipase activity occurred in digesta of chicks fed on low concentrations of proanthocyanidin-rich bean hulls but that at higher concentrations lipase activity was depressed.

Energy metabolizability measurements predicted that birds derived more energy from white-flowered varieties than from coloured-flowered beans which must in part be due to their better starch digestibility. Differences in energy metabolizability within the colouredflowered varieties were significant at $P<0.001$. Yapar \& Clandinin (1972) showed that removing the proanthocyanidins from rapeseed meal significantly increased its metabolizable energy value for chicks and that their addition to soya-bean meal lowered its metabolizable energy value.

Dietary protein level was shown to interact with the effect of hulls on the metabolizability of energy and digestibility of lipid but not of maize starch. When birds ingested diets containing hulls from the coloured-flowered varieties, a low level of protein resulted in a greater reduction in energy metabolizability while a high level of protein encouraged a greater digestion of lipid.

Both methods for the measurement of proanthocyanidins gave similar results. The disadvantage of the anthocyanidin formation method is that a purified proanthocyanidin standard is required for quantification since catechin does not form a colour product in the reaction. The vanillin method, however, can be readily employed using catechin as a standard if comparison between varieties in proanthocyanidin levels and not quantification is required.

In conclusion, since the effect of proanthocyanidins on starch digestion is difficult to predict, no precise inclusion level can be designated as inhibitory. Their anti-nutritional effect may depend on the length of time over which they are ingested as well as how innately digestible certain starches are to begin with. It would seem that one of the questions still 
requiring an answer is whether the dietary protein level would influence the effect of proanthocyanidin-rich hulls on the digestibility of bean starch.

The authors would like to thank Kim Henderson, Anne Knox (for help with the birds) and Lindsey McNeil (for contributing to the analytical work).

\section{REFERENCES}

Atkinson, A. C. (1985). Plots, Transformations and Regression. Oxford: Oxford Science Publications.

Butler, L. G., Price, M. L. \& Brotherton, J. E. (1982). Vanillin assay for proanthocyanidins (condensed tannins): Modification of the solvent for estimation of the degree of polymerisation. Journal of Agricultural Food Chemistry 30, 1087-1089.

Carré, B., Escartin, R., Melcion, J. P., Champ, M., Roux, G. \& Leclercq, B. (1987). Effect of pelleting and associations with maize or wheat on the nutritive value of smooth pea (Pisum sativum) seeds in adult cockerels. British Poultry Science 28, 219-229.

Conan, L. \& Carré, B. (1989). Effect of autoclaving on metabolisable energy value of smooth pea seed ( $P$ isum sativum) in growing chicks. Animal Feed Science and Technology 26, 337-345.

European Communities (1971). Determination of Crude Oils and Fats. Process A, Part 18, Animal Feedingstuffs, pp. 15-19. London: H.M. Stationery Office.

Fleming, S. E. \& Vose, J. R. (1979). Digestibility of raw and cooked starches from legume seeds using the laboratory rat. Journal of Nutrition 109, 2067-2075.

Griffiths, D. W. \& Moseley, G. (1980). The effect of diets containing field beans of high and low polyphenolic content on the activity of digestive enzymes in the intestine of rats. Journal of the Science of Food and Agriculture 31, 225-259.

Guillaume, P. J. (1978). Digestibilité des proteines, de l'amidon et des lipides de deux types de féverole (Vicia faba L.) crude en autoclave chez poussin. (Digestibility of protein, starch and lipid from two types of bean (Vicia faba L.) raw or autoclaved by young chicks). Archive für Geflugelkunde 42, 179-182.

Horigome, T., Kumar, R. \& Okamoto, K. (1988). Effects of condensed tannins prepared from leaves of fodder plants on digestive enzymes in vitro and in the intestine of rats. British Journal of Nutrition 60, 275-285.

Hudson, G. \& John, M. V. (1976). The automated determination of carbohydrate. Journal of the Science of Food and Agriculture 27, 681-687.

Lever, M. (1972). A new reaction for colorimetric determination of carbohydrates. Analytical Biochemistry 47 , 273-279.

Lindgren, E. (1975). The nutritive value of peas and beans for hens. Swedish Journal of Agricultural Research 5 , $159-161$.

Longstaff, M. \& McNab, J. M. (1986). Influence of site and variety on starch, hemicellulose and cellulose composition of wheats and their digestibilities by adult cockerels. British Poultry Science 27, 435-449.

Longstaff, M. \& McNab, J. M. (1987). Digestion of starch and fibre carbohydrates in peas by adult cockerels. British Poultry Science 28, 261-285.

Longstaff, M. \& MeNab, J. M. (1991 $a$ ). The inhibitory effects of hull polysaccharides and tannins of field beans (Vicia faba L.) on the digestion of amino acids, starch and lipid on digestive enzyme activities in young chicks. British Journal of Nutrition 65, 199-216.

Longstaff, M. \& McNab, J. M. (1991 b). The effect of concentration of tannin-rich field bean hulls ( Vicia faba L.) on activities of lipase and $\alpha$-amylase in digesta and pancreas and on the digestion of lipid and starch by young chicks. British Journal of Nutrition 66, 139-147.

McNab, J. M. \& Blair, J. C. (1988). Modified assay for true and apparent metabolisable energy based on tube feeding. British Poultry Science 29, 697-707.

Marquardt, R. R., Ward, A. T., Campbell, L. D. \& Cransfield, P. E. (1977). Purification, identification and characterisation of a growth inhibitor in faba beans (Vicia faba L. var. minor). Journal of Nutrition 107 , 1313-1324.

Nitsan, Z. (1971). Vicia faba beans vs. soybean meal as a source of protein. Journal of the Science of Food and Agriculture 22, 252-255.

Oh, H. I., Hoff, J. E., Armstrong, G. S. \& Hoff, L. A. (1980). Hydrophobic interaction in tannin-protein complexes. Journal of Agricultural Food Chemistry 28, 394-398.

Porter, L. J., Hrstich, L. N. \& Chan, B. G. (1986). The conversion of procyanidins and prodelphinidins to cyanidin and delphinidin. Phytochemistry 25, 223-230.

Schneeman, B. O. (1978). Effect of plant fiber on lipase, trypsin and chymotrypsin activity. Journal of Food Science 43, 634-635.

Snedecor, G. W. \& Cochran, W. G. (1967). Statistical Methods, 6th ed., pp. 364-368. Ames, Iowa: Iowa State University Press.

Stanogias, G. \& Pearce, G. R. (1985). The digestion of fibre by pigs. British Journal of Nutrition 53, 513-548. 
Tawflick, A. M. \& Mardon, C. J. (1985). Automated analytical method for the determination of individual sugars in mixtures of glucose, fructose and sucrose. Journal of the Science of Food and Agriculture 36, 621-627.

Yapar, Z. \& Clandinin, D. R. (1972). Effect of tannins in rapeseed meal on its nutritional value for chicks. Poultry Science 51, 222-228.

Yusté, P., Longstaff, M. \& McCorquodale, C. (1992). The effect of proanthocyanidin-rich hulls and proanthocyanidin extracts from bean (Vicia faba L.) hulls on nutrient digestibility and digestive enzyme activities in young chicks. British Journal of Nutrition 67, 57-65.

Yusté, P., Longstaff, M. A., McNab, J. M. \& McCorquodale, C. (1991). The digestibilities of semi purified starches from wheat, cassava, pea, bean and potato by adult cockerels and young chicks. Animal Feed Science and Technology 35, 289-300. 